Swarthmore College

Works

1992

\title{
The Red And The Green: The Rise And Fall Of Collectivized Agriculture In Marxist Regimes
}

Frederic L. Pryor

Swarthmore College, fpryor1@swarthmore.edu

Follow this and additional works at: https://works.swarthmore.edu/fac-economics

Part of the Economics Commons

Let us know how access to these works benefits you

\section{Recommended Citation}

Frederic L. Pryor. (1992). "The Red And The Green: The Rise And Fall Of Collectivized Agriculture In Marxist Regimes". The Red And The Green: The Rise And Fall Of Collectivized Agriculture In Marxist Regimes.

https://works.swarthmore.edu/fac-economics/91

This work is brought to you for free by Swarthmore College Libraries' Works. It has been accepted for inclusion in Economics Faculty Works by an authorized administrator of Works. For more information, please contact myworks@swarthmore.edu. 


\section{AN OVERVIEW OF THE MAJOR PROBLEMS AND THEMES}

The ReOrganization of agricultural production units into large-scale state and collective farms has been the most radical change of economic institutions implemented by Marxist governments. In contrast to the nationalization of industry and the replacement of the market by central planning and administration, this institutional change has transformed not only ownership and the way in which production units have functioned, but also the way in which laborers have gone about their work and have related to each other. The forced collectivization of agriculture has also been a searing historical experience in Marxist regimes, during which tens of millions died from starvation and mistreatment, while countless others suffered greatly as a result of the coercion. ${ }^{1}$

History has not unfolded as nineteenth-century Marxists expected. Socialist revolutions arising from domestic political forces have not occurred first in industrialized nations, but rather, for the most part, in predominantly agricultural countries with relatively low levels of economic development. Furthermore, despite commonplace notions about "peasant conservatism" and the difficulty in reorganizing and reforming agricultural production, Marxist regimes have paid particular attention to transforming the institutions of the rural sector, even while agriculture was the largest sector in the economy and when such changes were most difficult to implement. Furthermore, this institutional change occurred in many countries without extensive agricultural mechanization or high lev-

${ }^{1}$ Estimates of deaths in the Soviet Union resulting directly or indirectly from collectivization range from 11 million upward. For instance, according to the careful estimations of Robert Conquest (1986), elimination of the rich farmers (kulaks) was a crucial part of the collectivization drive in the Soviet Union and resulted in the deaths of 6.5 million. Another 8 million died in famines in the Ukraine and Kazakhstan that were an integral part of the program. In China, estimates of deaths from land reform and collectivization from 1946 through 1957 range from 250,000 to 5 million or more; Moise (1983, p. 142) estimates between 1 and 1.5 million for the land reform, although later evidence suggests this may be high. The real violence came in the period $1958-61$ when the government attempted to consolidate the collective farms into communes and precipitated a famine, when, according to the estimates of Banister (1987, p. 85), 30 million died. In most other Marxist regimes land reforms and collectivization were not so violent, although as discussed in chapter 4 , the governments employed considerable coercion. 
Marxist Regimes in the 1980s in the Western Hemisphere

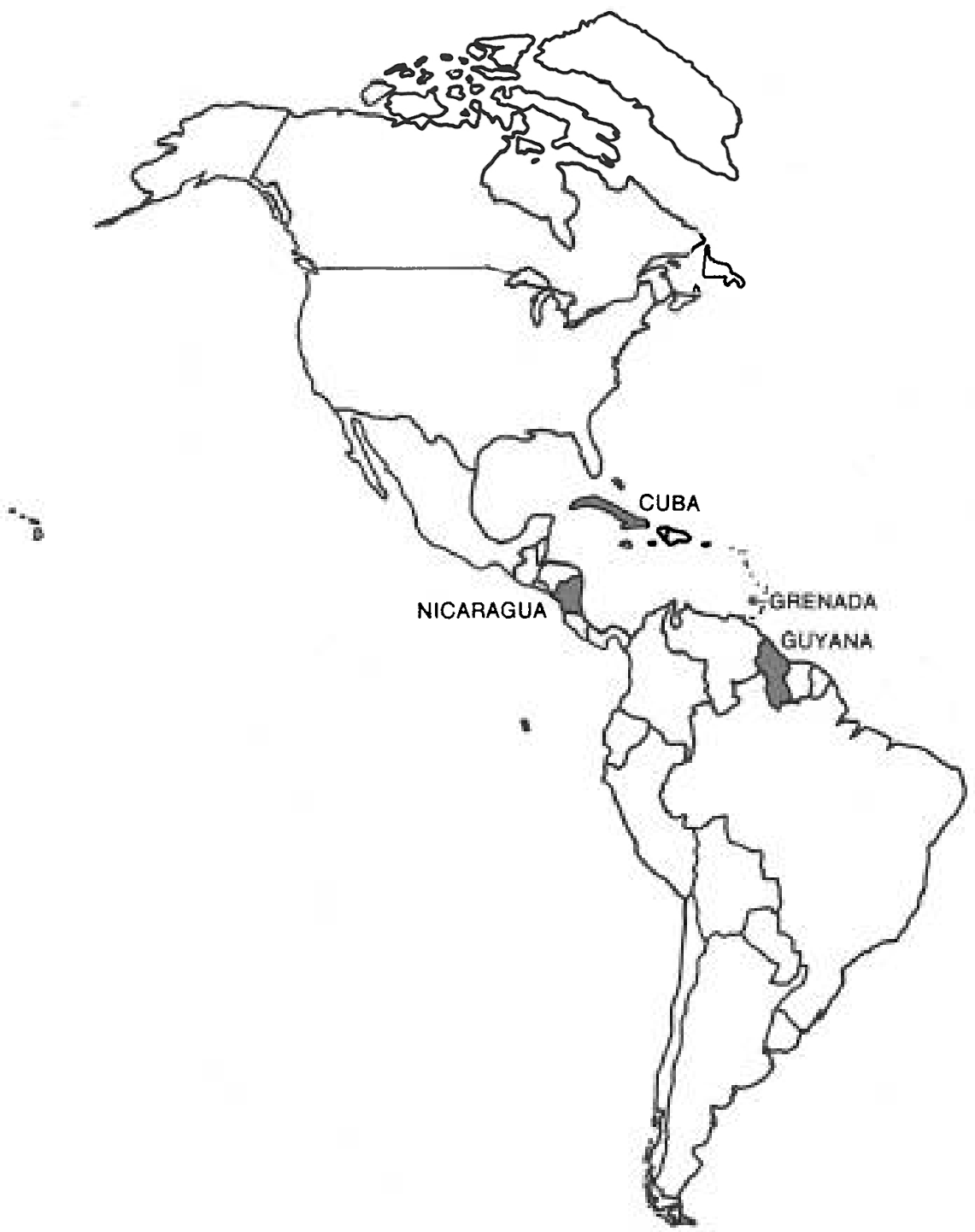




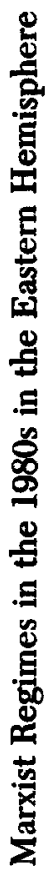

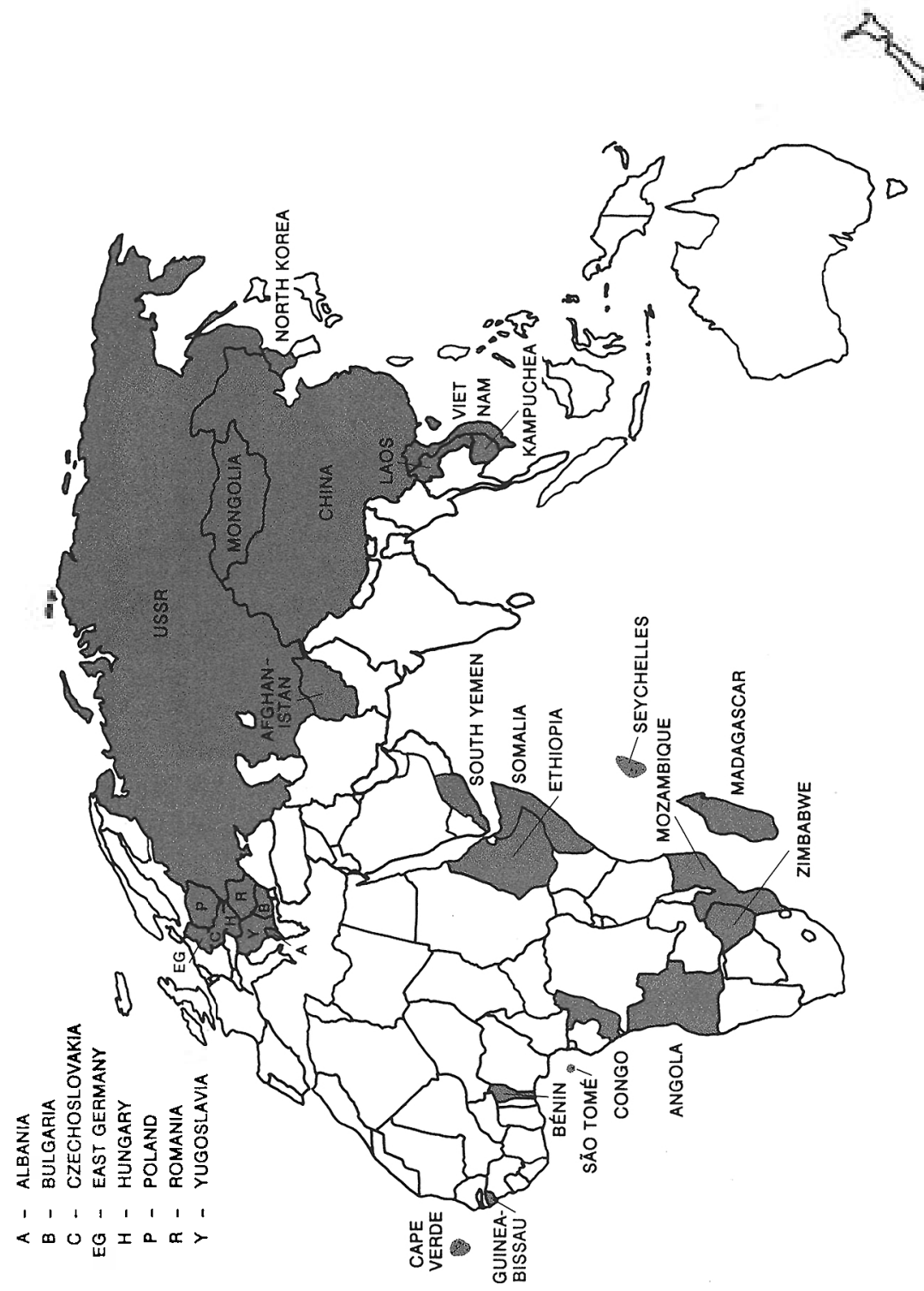


els of rural education and where administration of large-scale agriculture was probably neither cost effective nor necessary. In Marxist terminology, the relations of production were probably too advanced in comparison to the forces of production. Finally, although Marx emphasized the relatively similar paths of development of industry and agriculture and laid great moral stress on the value of all types of physical labor, most of these Marxist governments have organized the two sectors in dissimilar ways and have treated urban and rural workers quite differently, often to the disadvantage of the latter.

Contemporary Marxists, particularly those influenced by the ideas of Stalin, have ready explanations for each of these apparent deviations from classical Marxist doctrines. But in analyzing such issues, Marxists of any stripe have greater difficulty in answering a more basic question: What is the best way for a government professing to follow the ideas of Marx and Lenin to organize agriculture so as to enhance the economic development of an entire nation? Although Marxist-Leninist doctrines about the organization of agriculture may leave much to be desired, discussion in the West about the optimal organization of agriculture is certainly not much more advanced. Enormous attention has been focused on "saving the family farm," but many more organizational issues need to be discussed. Indeed, relatively little data are available to study many critical problems-for example, the horizontal linkages between farms or vertical linkages between farms and either upstream or downstream enterprises in the chain of production. In contrast to the analysis of the organization of industry, no formal academic field studying the organization of agriculture exists; no scholarly journals devoted to the topic fill the shelves of libraries; and no standard analytic methods are available to resolve disputes on policy questions.

First and foremost, this is a study about the organization of Marxist economies, both in theory and practice. I have chosen agriculture because it allows a series of analytic issues to be examined in an easier fashion than other sectors would allow. This book is an examination of ideas and their influence, and how, given the heterogeneity of agriculture, these ideas can be stretched to their furthest limits. But this is also an empirical investigation of the origins, organization, and development of agriculture in thirty-three identified Marxist regimes shown on the maps here. In order to provide some perspective, I also investigate certain aspects of the organization of agriculture in market economies, both to test various Marxist propositions about the development of agriculture and to illuminate the differences and similarities of agricultural organization in various economic systems.

Finally, this book is an attempt to synthesize a vast and straggly scholarly literature in both East and West on a number of theoretical and em- 
pirical issues about agricultural organization. In order to keep the discussion manageable, many issues cannot be discussed in depth and the reader is referred to the appropriate references for further analysis. I must also leave to others the task of carrying out detailed case studies to advance our knowledge of agriculture in individual countries. Nevertheless, I hope that the analytical framework and the comparative perspective provided herein enriches the case-study approach by allowing a separation of key causal factors. For instance, which aspects of agricultural organization and policy can be attributed to Marxist-Leninist doctrines? Or to the type of agriculture practiced in various countries? Or to the particular historical circumstances of the different nations? Or to the decisions arising from the unique political mechanisms of particular nations? I also try to show why, despite the deficiencies in performance of collectivized agriculture, it is highly doubtful that state and collective farms will disappear quickly, even in some nations where Marxist parties have been voted out of power.

But first it is necessary to delimit the topic, especially by defining two crucial terms, socialist agriculture and Marxist regimes, so that the subject matter and the sample can be specified. Then I briefly summarize the role of agriculture in the sample countries in order to provide an overview of the economic context within which agriculture is organized. Finally, I indicate briefly the major questions investigated and the path along which they are approached.

\section{SOCIALIST AGRICULTURE}

For purposes of this study I define socialist agriculture in terms of institutions of production rather than particular types of governmental intervention. Collectivization is the process including nationalization or expropriation of private farms and the creation of large-scale cooperative and state farms. For most of recorded history, governments have interceded in the agricultural sector in order to reinforce or suppress market forces and channels of distribution, to encourage production, or to influence rural incomes. For this reason governmental intervention per se provides little indication about the economic system of agriculture. The definition of socialist agriculture as represented by institutions of production gives rise, however, to a number of complications.

\section{General Considerations}

Marx and Engels told us little about institutions of agricultural production functioning in socialist economies. They made only scattered comments from which emerges a murky picture of what agriculture would be 
like when full communism arrives. ${ }^{2}$ They foresaw an economy of high productivity and disciplined workers, but with no markets or money, so that exchange of products between urban and rural areas would, in some manner, be "direct." Such an arrangement would be facilitated by the fact that the ideas and outlooks of those living in the two areas would be similar.

Up to now, Kampuchea between 1975 and 1978 has been the only Marxist nation to attempt to realize such a communist agricultural system. The Pol Pot regime expropriated all land, formed relatively largescale, self-sufficient production units, and effectively eliminated both trade and money. Party or government cadre-often soldiers in their teens-directed the labor force, providing workers with agricultural inputs received from the central government, and distributing food rations, housing, and clothing according to norms unrelated to an individual's work. Food was also communally consumed. The farms, in turn, supplied the central government with deliveries of particular goods. ${ }^{3}$ The scholarly community has focused little attention on this unique attempt to realize Marx's vision, in part because the mass murders accompanying this Kampuchean transformation have been more important to study, and in part because high productivity, a crucial aspect of full communism, was not achieved in this nation.

More usual production institutions of socialist agriculture are state farms, collective farms, and communes, all of which are forms of largescale agriculture. It is, of course, possible to have a socialized urban sector without a socialist agricultural sector, a situation arising in Poland and Yugoslavia from the mid-1950s to the present, as well as in a number of Marxist African nations. It is also possible to conceive of a socialist agricultural sector that produces a plantation crop exhibiting economies of scale, combined with a predominantly private urban sector that provides complementary products and services. This latter system does not appear to be stable in the long run and is not exemplified in any of the nations of the sample. ${ }^{4}$ Socialist agricultural institutions are usually accompanied

2 This discussion is based on Pryor (1985b), which provides all of the relevant quotations.

${ }^{3}$ A highly detailed eyewitness account of life on one of these units is provided by May (1986), and other interesting views are presented in Kiernan and Boua (1982 chap. 10). Most journalists and scholars have focused their attention on such notable aspects of this system as the extreme cruelty of the government and the division of the population into different classes so that each received different amounts of food and other rations, rather than on more mundane aspects of how the economy worked. By far the most systematic examination of the economic system is by Twining (1989), although many gaps in his study remain due to lack of reliable information.

${ }^{4}$ It has been most closely approximated in São Tomé and Seychelles. Before independence, both were predominantly plantation economies in which the plantations were primarily owned by foreigners (especially in the former). São Tomé immediately nationalized 
by certain other features that are neither necessary nor sufficient for the system to function, for instance, rules against firing workers on state farms or removing members from collective farms.

It is important to emphasize that communal agricultural systems found in some developing nations, especially in sub-Saharan Africa, have little in common with socialist agriculture. In the former systems, the community can place restrictions on what a farmer can do with the land, on the date when certain agricultural activities can begin or end, and even on the farming techniques that are employed. In some cases land is also distributed by traditional political leaders, but nevertheless, families farm the land individually and individual wealth is not merged. Of course, cooperative work efforts occur and may be of considerable significance, but they are both informal and voluntary; these arrangements include trading labor or participating in work gangs that spend a certain amount of time on the farms of each member (Pryor 1977). In contrast to the beliefs of African political leaders such as Julius Nyerere of Tanzania or Leopold Senghor of Senegal, experience in Africa has shown that communal agriculture has little in common with collectivized farming and, indeed, these systems do not lead easily to socialist agriculture.

\section{State Farms}

A state farm is simply a factory-in-the-field that is owned by the government. In most cases the government or a government board appoints a director, who hires workers and manages the farm in the same manner as the hired manager of a capitalist plantation. Although the workers may receive bonuses based on production, their primary source of income is a wage, and the government thus absorbs most risks of production.

Some cases are, however, hard to classify. For instance, in Yugoslavia the public sector has certain residual rights in the nonprivate farms (for example, the members cannot sell the assets and pocket the receipts), so that these enterprises might be considered state farms. Nevertheless, these "socially owned" farms operate essentially as producer cooperatives and are run by worker councils, which set the basic policy guidelines and hire the farm managers. Thus these farms combine features of both systems. In other East European nations, as I will indicate, the difference between state and collective farms has eroded.

State farms can be formal production units ultimately administered by a central authority such as a ministry of agriculture. Other types of state farms, sometimes called "institutional farms," include those farms at- 
tached to state-owned industrial plants such as the podkhozi in the USSR, farms operated by special development agencies (for instance, in Seychelles), farms operated by the army, local governments, primary schools, or universities (for example, experimental stations) or farms operated by the Marxist party (for instance, in the Congo). In most of the countries these institutional farms hold only a small percentage of the land in the state farm sector; a notable exception is Bénin, however, where they constitute 95 percent of the state farm sector. ${ }^{5}$ In other countries, these institutional farms, although relatively small in total area, increased in importance. Most notably, during the 1980s the government of the Soviet Union encouraged factories to administer farms in order to supply food for factory canteens. As Hedlund has emphasized (1989), these attempts to increase total farm output often divert specialized managerial resources in industry from where they can best be employed.

According to Stalinist dogma, the state farm is a "higher form of socialism" than the collective farm, and until the late 1980s some Marxist regimes such as Albania, Mongolia, Romania, and the USSR were slowly converting their collective farms to state farms. By no means is this dogma universally accepted: during the mid- and late-1980s Nicaragua converted a number of its original state farms into cooperatives (or even divided them up into private farms). The government of Seychelles has also announced its intention to transform its state farms into cooperatives once the state farms are operating on a profitable basis; this does not, however, seem likely to occur in the near future.

State farms are, of course, not unique to socialism, and they also exist in almost all capitalist nations, serving either as experimental farms or in some cases a source of revenue when they are leased out to private farmers. These farms represent either remnants of the original "crown land," or of past land reforms, or of deliberate attempts by the government to set up a limited number of government farms. Indeed, some instances can also be cited in which nominally capitalist nations such as Malawi have more extensive and more successful state farm systems than nominally Marxist regimes such as Madagascar (Pryor 1990c).

\section{Collective Farms}

I use the term collective farm to designate a farm where production is carried out jointly (a group of people work together under a single man-

${ }^{5}$ According to the data from SEV (annual, 1988), in the mid-1980s such institutional farms amounted to about 16 percent of total farm land in Romania, 9 percent in Czechoslovakia, and less than 6 percent in the other Council of Mutual Economic Assistance (CMEA) nations. Hedlund (1989) has an illuminating analysis of the podhozy in the USSR, while Després and Khischuk (1990) explore those operated by the military. The Bénin 
agement) and where the net receipts or income of the farm (receipts after taxes have been paid and agricultural inputs have been purchased) are divided among the members according to a formula that takes into partial account the amount of work the members contributed to the common effort. The government contract with the farm usually has two parts: a fixed rent (that is, compulsory deliveries of certain crops at a specified price) and an agreement to buy all produce above this limit, usually at a higher price. The collective farm members bear all risks of production shortfalls. In some cases the government has modified this residual-income principle by providing a floor income for members of the cooperative; in these cases the farms receive a government subsidy or loan if net receipts are not sufficient to cover expenses and payments to members. In some countries (e.g., Cuba, Hungary, and Bulgaria until 1959) these farms paid rent to the farmers who brought land into the collective; in other countries no compensation was paid. In some countries the land belonged to the collective as a whole; in other countries, to the government (a matter discussed in greater detail in chapter 3); and in still other countries (e.g., most of the nations of East Europe) to the people who brought the land into the collective, or their heirs. In some countries (e.g., Yugoslavia and, to a lesser degree, Bulgaria and Cuba in the late 1980s) the farms had certain elements of self-management with elected representatives on the administrative council of the farm; in other countries, the farm was administered in a highly centralized fashion.

As Adam Fforde (1989, p. xii) warns us: "Knowledge of formal, or legally constituted, social structures does not necessarily tell us much about underlying 'reality." "For purposes of discussion in the following chapters, it is useful to keep in mind that collective farms can operate in quite different ways, even with the same formal rules:

1. In a cooperative farm the members appoint their own managers and make their own decisions. They are voluntary organizations, and, in their occasional appearance in several Marxist regimes, they have often had quite different members from year to year (e.g., in Laos, as shown by Evans 1990, chap. 4). Such a producer cooperative must be distinguished from a service cooperative, in which a group of people band together to market their crop, buy agricultural inputs, rent a combine, hire a technician, or participate together in some project perhaps related to farming but not directly involved in all phases of the productive process. Both of

case, discussed briefly by Godin (1986, pp. 201-3), has arisen because foreign plantations were minuscule (less than three thousand hectares in the 1930s) so that the government did not find much land to nationalize easily. Most of the institutional farms in Bénin (64 percent of the area) were plots of towns and schools which, relying on unpaid labor, produced a crop whose sales yielded funds to finance investment in infrastructure. Such farms, of course, acted to convert a tax-in-kind to money revenues. The other farms were usually vertically integrated agricultural processing enterprises owned by the state. 
these, of course, are also different from a consumer cooperative, in which consumers unite to purchase in bulk in order to reduce the retail margin they otherwise would pay. Although simple, these distinctions are often blurred and, as a result, have given rise to enormous confusion; for instance, the varied interpretations of Lenin's last pronouncement on cooperatives (see chapter 2). A producer cooperative must also be distinguished from various forms of mutual aid or cooperative arrangements among farmers who, however, farm their lands individually.

2. In a pseudo-cooperative farm the unit has few cooperative elements and is really managed as a state farm. One type of pseudo-cooperative farm existed in the USSR for many decades: the state and party appointed the farm directors and expected them to meet production and other goals determined by the government. The directors, in turn, managed the farm in an hierarchical fashion; members had almost no influence over who led them, how they were led, or what work they carried out. These pseudo-cooperative farms had for several decades a secondclass status: they received no state subsidies; they always had a lower priority in obtaining scarce agricultural inputs; they could not own their own machines but had to rent machine services from the Machine Tractor Station (MTS); their older members received no social insurance payments from the government; and the members had to absorb the agricultural risks by receiving a share of the net income, rather than a fixed wage. A strange type of pseudo-cooperative farm occurred in Bénin in the 1970s and 1980s where farmers in a particular area were forced to combine their land and rent it to a cooperative (a périmètre or coopérative d'aménagement rural) which, in turn, was managed by a team from a state company. Both the landlords and the landless in the area also had the option of working for the cooperative and receiving a wage. ${ }^{6}$ Still other variants of pseudo-cooperatives could be found in other countries. Pseudo-cooperatives were most often found in nations where the party and/or government was highly organized in rural areas; for example, many East European nations and China.

3. In a nominal-cooperative farm the collective unit can serve either as a mask of the operations for a private company or of agriculturalists actually farming their land individually. One interesting example of the former has occurred in Guyana (Standing and Szal 1979, pp. 72-73; Thomas 1983) where groups of private individuals, such as urban civil servants, organized cooperatives. They obtained free land, low-interest credit, and tax privileges and then farmed the land individually, hiring outside labor for the actual farm work. Other Guyanese cooperatives had "dormant

${ }^{6}$ This type of pseudocooperative began under a previous non-Marxist government. Mondjannagni (1977) and Godin (1986) provide further details. 
members" with formal voting rights that allow a private firm to call itself a cooperative. A different type of nominal-cooperative farm existed in Viet Nam during the 1970s where the collective farm often served as a mask for individuals or hamlets to carry out their individual agricultural activities with a minimum of outside interference. ${ }^{7}$ In the highlands of Georgia in the Soviet Union, the collective farms also appeared to play a strategic role in the private economy of its members and, as such, were different from collectives in the Russian Republic. ${ }^{8}$ In different forms nominal-collectives also arose in still other countries such as Cape Verde (or the "pre-cooperatives" in the Congo), where the size of the collective fields has been relatively small in comparison to the private fields on the same farm. In Laos, collective farms were so loosely organized that for many years farmers could pull their land out of the cooperative relatively easily (Evans 1990). The Somali "range cooperatives" represented a nominal-cooperative in a herding context: cattle were held privately and pieces of range land were assigned to individual families who, in some manner, were supposed to cooperate with each other and to obey the grazing rules set forth by the government. Sometimes political authorities foster nominal-cooperatives as the first step toward full cooperativization; in other cases nominal-cooperatives arise where party discipline is weak in the rural areas, a situation occurring in most Third World Marxist regimes. Nominal cooperatives are most likely to be found where the state and party are weakly organized in the rural areas; for instance, Africa, Yemen, and southeast Asian nations such as Laos and Viet Nam.

Collective farms are not the exclusive property of Marxist regimes and they have been sponsored in some form by non-Marxist governments as well. For instance, in the 1980s they existed on a large scale in Algeria, Israel, and Tanzania and, on a lesser scale, in other nations such as Ghana. Still other non-Marxist regimes feature small-scale cooperative farms, either in the form of small groups of people voluntarily banding together to farm jointly or in the form of small-scale experiments under

\footnotetext{
${ }^{7}$ According to Fforde (1989, pp. 6, 80), up to 75 percent of the collective farms in North Viet Nam were nominal in the late 1970s. His definition of nominal is somewhat looser than mine, since he includes farms in which the key decision-making unit is the brigade or hamlet and, although some production is collective, some important economic activities such as pig raising were carried out privately.

${ }^{8}$ Dragadze's village study (1988) suggests that a major function of the collective farm has been to supply foodstuffs to members that they could not obtain in stores and that the farm was organized in a sufficiently loose fashion so that one family member often substituted for the formal member in order to accumulate family work points for the distribution of agricultural products not delivered to the state. Moskoff (1984, p. 159) presents data showing that collective farm workers in Georgia worked on the farm many fewer days than those in the Russian Republic.
} 
governmental aegis; an example of this occurred in the United States in the late 1930s. ${ }^{9}$

\section{Communes}

The term commune has widely different meanings, but in this study I use the word to describe a large-scale farm unit that has governmental powers as well; that is, the same authorities carry out both economic and political functions. ${ }^{10}$ These units of production could be found in China from the late 1950s to the early 1980s, Mongolia from the late 1950s through the late 1980s, Kampuchea under Pol Pot, or to a much lesser extent, Ethiopia in the late 1970s (in those cases where some Peasant Associations formed cooperatives). I omit from consideration those situations where economic and political power structures are fused in an informal manner. Most often these large-scale communes operate according to the cooperative principle in the division of the income, although in some cases the salary system appears to be used.

In many cases it is difficult to decide whether a particular production unit is a cooperative or part of a commune in which government authorities at a local level play a critical role in the management of the unit. For instance, in North Korea after 1961, the County (Kun) Agricultural Management Committee received extensive powers to participate in farm decision-making, although the cooperatives still retained their formal identity. ${ }^{11}$ If this means that the county governments are the predominant unit in farm decision-making, then North Korean collectives must be classified as communes, with the smaller units acting as profit centers; the exact manner in which decision-making powers are distributed between the county and the farm are difficult for an outsider to determine. Similarly, by the late $1960 \mathrm{~s}$ in China, the teams (in this case, villages) were profit centers with considerable autonomy. If the central communal administration had relatively little power, then the Chinese communes

${ }^{9}$ Infield (1945) tells the bizarre story of the 262 cooperative and state farms established in the late 1930s in the United States. Zablocki (1980) describes voluntary efforts to establish cooperative farms in the United States thorough the mid-1970s.

${ }^{10}$ My use of the term commune should not be confused with other meanings of the word; e.g., the cooperative farms (found in the USSR in the 1920s and discussed by Wesson [1963]) where the members eat or live together, or the village communities of nineteenthcentury Russia, or the small governmental units (without any agricultural functions) in some countries such as France or Yugoslavia. These units are not discussed in this study.

11 I refer to East Germany, North Korea, South Yemen, and the Congo, rather than the German Democratic Republic, the Democratic People's Republic of Korea, the People's Democratic Republic of Yemen, and the People's Republic of the Congo so as to avoid confusion with their capitalist counterparts, which might also be considered democratic, albeit in a different sense. 
should be considered as a network of cooperative farms operating within a governmental unit called a commune. Although these kinds of definitional problems raise difficulties of classification, they do not impede other aspects of this analysis.

\section{A Case Study: The USSR}

We can understand these different forms of agriculture organization more concretely and, at the same time, gain a clearer idea about some of the major themes of this study by examining briefly the experience of the Soviet Union. I must stress, however, that the Soviet experience is not typical of other Marxist regimes and that the purpose of the many minicase studies of countries in this book is to provide flesh for the barebone definitions and generalizations.

Before the major Soviet collectivization drive began in the last two months of 1929, individual peasants farmed over 95 percent of the land; moreover, the overwhelming majority of these peasants belonged to village communities, which controlled economic life of the village (Nove 1969, p. 106). The government's role in agriculture was primarily as a purchaser of grain; and in the mid-1920s it bought roughly three-quarters of the marketed grain. As noted in chapter 3, unlike most Marxist regimes, collectivization had not been preceded by a government-directed land reform, although considerable ownership changes had occurred through peasant land takeovers after the revolution.

Although in chapter $2 \mathrm{I}$ discuss in detail the many reasons for collectivization, three economic reasons appeared most important in the USSR: the need to achieve greater production and marketed sales through the alleged economies of large-scale farming; the necessity to modernize agriculture; and the desire to force farmers to sell their crops to the government at low prices so that the profits could be used to finance industrialization. The degrees to which these and other goals of collectivization were achieved are analyzed for many Marxist regimes in chapters 7 and 8.

The government consolidated private farms into collectivized farms with the aid of specially recruited urban workers and party officials. Within several months more than half of the peasant population had joined the collectives. The administrative excesses committed to achieve these results were so extreme that in March 1930 Stalin, who initiated this "voluntary" drive, attempted to deflect criticism by placing most of the blame on the zeal of local officials. Other Marxist regimes that collectivized later learned a great deal from these policy lessons (see chapter 4). Subsequently, more than half of the collective farms disbanded, but the offensive resumed and in 1934 more than three-quarters of all peas- 
ant households and crop areas were collectivized and organized into farms averaging roughly seventy households and four hundred hectares. Few of these collective farms were genuine producer cooperativesmany were pseudo-cooperatives directed by cadre selected by the party or government and most of the remainder were nominal-cooperatives formed by farmers wishing to avoid outside interference in their activities. Over time, however, most of the nominal cooperatives were transformed into pseudo-cooperatives. Autonomous and genuine producer cooperatives were not a feature of Soviet agriculture.

In the mid-1920s Stalin had stressed the formation of large state farms, but the difficulties inherent in this policy rapidly became apparent. As a result, in the collectivization drive, the government placed most stress on the formation of collective farms. In 1934, for instance, state farms covered less than 10 percent of total crop area. They were somewhat larger than the collective farms and averaged about 430 workers and 2,400 hectares (USSR, Central Statistical Board 1969, p. 127).

The state farms received detailed output, input, and investment plans; furthermore, if costs could not be met, they received subsidies or loans. They were less autonomous than collective farms, which received delivery and input quotas of a less detailed nature, but which could not rely on subsidies. In the early years farm officials carried out considerable experimentation on organizing and administering these collective and state farms, a topic receiving greater attention in chapter 5 .

After the Second World War the government began to consolidate collective farms into much larger units and, in addition, to transform many into state farms. After the death of Stalin in 1953, these trends accelerated so that by the late 1980 s state farms comprised more than twice the land of the collective farms (see table 5.1). Furthermore, the government dissolved the MTSs and partly sold, partly gave away their equipment to the collective farms. Collective farmers, moreover, began to receive a minimum wage and, although producer prices paid to these farms were increased several-fold, subsidies to these farms increased dramatically, as did their unpaid debts, which were periodically cancelled. In brief, the differences between the collective and state farms began to disappear, a trend apparent in other Marxist regimes as well.

In the late 1980s the Gorbachev government took the first tentative moves toward decollectivization; that is, the conversion of state and collective farms into either private (corporate or individual) farms, or tenant farms with long-term leases, or genuine producer cooperatives. In the USSR these policy steps were taken mainly in the form of leasehold contracts to households and, in certain republics such as Georgia, the breaking up of highly unprofitable collective and state farms into individual farms. As indicated in chapters 10 and 11, by the end of 1990 this decol- 
lectivization movement was still in its initial stages, in contrast with a number of other nations under discussion in this book.

The aims of collectivization and the organization of agriculture that resulted had a considerable impact both on the functioning of the farms (see chapters 5 and 6) and on the policies pursued by the government to encourage production (see chapter 7). These elements, in turn, greatly influenced the performance of the agricultural sector (see chapter 8). Further consideration of these implications of the organizational forms, however, would put us far ahead of our story.

\section{The Institutional Mix}

As I discuss in greater detail in chapters 3 and 4 , the institutions of socialist agriculture are by no means uniform among Marxist regimes. Only a few Marxist regimes have communes, and the mix between private, cooperative, and state farms varies considerably. To provide an overview, four clusters of countries can be distinguished in the 1980s: (1) Some Marxist regimes did not have a very large socialist agricultural sector. In some cases, for example, the majority of African Marxist regimes, as well as Grenada, Poland, and Yugoslavia, this was because not much collectivization was carried out. In other cases such as China, Kampuchea, Laos, or Viet Nam in the late 1980s, this was because these nations carried out some type of decollectivization; (2) In other Marxist regimes, mostly in East Europe, the agricultural sector was dominated by collective farms; (3) In still other Marxist nations, most notably Bulgaria (in the mid1980s), Cuba, Guyana, São Tomé, and the USSR, state farms predominated; and (4) In a final group including China (in the 1970s) and Mongolia (in the 1970s and 1980s) the agricultural sector was dominated by communes with the subunits run as pseudo-cooperatives. An important question explored in chapter 3 is why particular nations have adopted one or another form of socialist agriculture.

\section{MARXIST RegIMeS}

The purpose of this brief discussion is to select the sample for analysis, not to condemn or praise certain nations. I choose my particular definition for analytical convenience to examine particular questions; for other types of comparative studies, a much different definition of "Marxist regime" may be more suitable. In particular, I am interested in the impact and implementation of Marxist ideas and have shaped my definition accordingly.

Since Marx wrote little about the operation of socialist economies or agriculture, some readers may be uncomfortable with my terminology 
and wish to label the countries in my sample as "Marxist-Leninist" or "socialist" or "communist." Each of these labels also raises problems, especially for developing nations whose governments have embraced Marxist ideas and ideals, but which have neither a Leninist-type political party nor the resources to implement the type of welfare and other programs associated with socialism.

\section{The Approach of This Study}

The classical definition of socialism refers to ownership of the means of production. Table 1.1 provides a rough measure of the importance of governmental ownership. A brief glance at the table reveals that this share varies enormously among the countries, in part because some nations have started along this path at an earlier date and in part because various governments have forced the pace of nationalization at different speeds. The pattern of nationalization is quite distinct (a matter discussed for East Europe in Pryor 1973, chapter 2). For our purposes it is necessary to note only that the degree of nationalization in agriculture is generally much lower in most other sectors; the exceptions, such as São Tomé and Seychelles, have arisen from very particular historical circumstances. It should also be mentioned that certain non-Marxist socialist countries have a much higher percentage of workers in the state and cooperative sector (59.8 percent in Algeria in the early 1980s, according to Algeria 1981 , p. 59) than most of the countries in this table.

As I have argued at length elsewhere (Pryor 1986, chap. 8), distinguishing Marxist regimes by ownership or by other economic criteria such as the relative share of governmental expenditures in the gross domestic product (GDP), or replacement of market mechanisms of allocation by governmental central planning and economic administration, is not very useful since most Third World nations calling themselves Marxist and attempting to achieve a socialist economy would be excluded from this list. For the same reason distinguishing Marxist regimes by the degree to which they are pursuing general socialist development policies such as increasing social equality and participation in national decisionmaking, development of idealistic individuals unfettered by acquisitive motives, or reduction of alienation also does not seem helpful.

A more fruitful approach in selecting a sample of Marxist regimes employs both ideological and implementation criteria. A necessary but not sufficient ideological condition is whether the leading officials in the government have been strongly influenced by Marxist ideas; that is, if a communist party controls the government or if the elite in power has been strongly influenced by some version of Marxism. In some Third World countries such as Guinea-Bissau or São Tomé, an official declaration of 
TABLE 1.1

The Share of the Labor Force in the Public and Cooperative Sectors

\begin{tabular}{|c|c|c|c|c|c|c|c|}
\hline & \multirow[b]{3}{*}{ Date } & \multicolumn{3}{|c|}{ State sector } & \multicolumn{3}{|c|}{ Cooperative sector } \\
\hline & & \multicolumn{3}{|c|}{ Other } & \multicolumn{3}{|c|}{ Other } \\
\hline & & $A F F$ & Sectors & Total & $A F F$ & Sectors & Total \\
\hline \multicolumn{8}{|l|}{ Africa } \\
\hline Angola & 1984 & $2.2 \%$ & $30-50 \%$ & $9-14 \%$ & & & \\
\hline Bénin & 1980 & 0.4 & 11.7 & 3.5 & & & \\
\hline Cape Verde & 1985 & n.a. & n.a. & 51.2 & & & \\
\hline Congo & 1982 & n.a. & n.a. & 14.7 & & & \\
\hline Ethiopia & n.a. & n.a. & n.a. & n.a. & & & \\
\hline Guinea-Bissau & 1984 & n.a. & n.a. & 13.4 & & & \\
\hline Madagascar & 1980 & 0.8 & 41.3 & 5.3 & & & \\
\hline Mozambique & 1980 & 2.9 & 70.4 & 12.9 & $0.6 \%$ & $0.4 \%$ & $0.5 \%$ \\
\hline São Tomé & 1981 & 86.0 & 60.0 & 74.5 & & & \\
\hline Seychelles & 1985 & $\mathbf{5 7 . 5}$ & 58.3 & 58.2 & & & \\
\hline Somalia & 1981 & 0.6 & 47.8 & 4.8 & 1.7 & 8.4 & 2.2 \\
\hline Zimbabwe & 1983 & 4.0 & 28.4 & 25.5 & & & \\
\hline \multicolumn{8}{|l|}{ Americas } \\
\hline Cuba & 1981 & 75.6 & 98.5 & 93.3 & 3.8 & 0.0 & 0.9 \\
\hline Grenada & 1981 & 15.7 & 38.1 & 31.9 & & & \\
\hline Guyana & 1980 & 42.3 & 23.4 & 25.6 & & & \\
\hline Nicaragua & 1982 & 11.0 & 33.0 & 22.8 & 2.2 & 0.0 & 1.0 \\
\hline \multicolumn{8}{|l|}{ Asia } \\
\hline Afghanistan & 1981 & 0.6 & 26.1 & 10.6 & 8.7 & 0.0 & 5.3 \\
\hline China & 1986 & 3.3 & 64.4 & 27.1 & 0.2 & 16.9 & 6.7 \\
\hline Kampuchea & n.a. & n.a. & n.a. & n.a. & & & \\
\hline Korea, North & 1965 & 8.0 & 100.0 & 43.2 & 92.0 & 0.0 & 56.8 \\
\hline Laos & n.a. & n.a. & n.a. & n.a. & & & \\
\hline Mongolia & 1979 & n.a. & n.a. & 63.1 & n.a. & n.a. & 36.6 \\
\hline Viet Nam & 1984 & 10.9 & 21.1 & 13.8 & 70.0 & n.a. & 50.3 \\
\hline Yemen, South & 1982 & 10.7 & 47.5 & 42.8 & 30.7 & 5.3 & 5.5 \\
\hline \multicolumn{8}{|l|}{ Europe } \\
\hline Albania & 1979 & n.a. & n.a. & 49.8 & & & \\
\hline Bulgaria & 1965 & 16.1 & 90.1 & $\mathbf{5 7 . 3}$ & 82.7 & 8.4 & 41.3 \\
\hline Czechoslovakia & 1985 & 99.1 & 98.8 & \multicolumn{4}{|c|}{98.9 (combined public and cooperative) } \\
\hline Germany, East & 1987 & 19.8 & 87.6 & 80.2 & 78.7 & 7.0 & 14.8 \\
\hline Hungary & 1987 & 50.4 & 11.6 & 86.8 & 47.0 & 11.6 & 7.4 \\
\hline Poland & 1978 & 14.1 & 96.4 & 71.6 & 6.8 & n.a. & 2.0 \\
\hline Romania & 1977 & 11.9 & 92.5 & 62.8 & 72.2 & 5.9 & 30.3 \\
\hline USSR & 1970 & 39.4 & 99.2 & 84.1 & 59.5 & 0.9 & 15.5 \\
\hline Yugoslavia & 1981 & 11.6 & 94.0 & 68.5 & 0.4 & n.a. & n.a. \\
\hline
\end{tabular}

Source: See Statistical Note A. For Zimbabwe and South Yemen, the percentage of production is used; for Poland, the state sector outside agriculture includes the small number of cooperatives. For several other countries the calculations are very approximate, so "other sectors" cannot be easily estimated.

Notes: AFF = agriculture, forestry, and fishing.

The percentages represent the share of the economically active population who are working in enterprises owned either by some level of government or cooperatively. In cases of mixed ownership, the practices of the statistical agencies of each nation are used, since sufficient data to adjust for complete 
this adherence has not been made, but it is clear from other evidence that Marxist ideas have played a crucial and open role in intellectual life of the ruling party. The strength of the commitment is important, because some political leaders such as Jean-Bedel Bokassa of the Central African Republic have, at one time or another, proclaimed their country to be Marxist or to be "following" scientific socialism primarily to obtain foreign aid from the Soviet Union.

Ideally we should supplement self-identification with a checklist of specific beliefs; for example, in the existence of a vanguard party serving as the leading political/economic force in the nation, in the importance of the class struggle in forging a socialist nation, in scientific socialism transcending all local characteristics of the society, and so forth. But in many cases it is difficult to determine the official party line on these matters or, when these phrases are used, to ascertain what they really mean or the strength of belief in these doctrines. Thus these more sophisticated ideological criteria cannot easily be employed.

Self-identification, of course, has its own difficulties and its use raises the problem of the audience and purpose for such symbolic declarations. For tactical purposes, the party or governing elites in some countries have not openly announced the influence of Marxist ideas on their policies. The self-identification criterion must be modified to include three other cases: (a) Particular governments such as the People's Revolutionary Government (PRG) of Grenada, which readily acknowledged the influence of Marxism in its closed councils (Pryor 1986), but for political reasons did not make this announcement publicly; (b) Other governments such as Cape Verde were dominated by parties founded by those who were Marxist, but they did not choose to identify themselves in this manner in public and we have no information about their self identification behind closed doors. Without evidence to the contrary, we must infer that they are Marxist parties; (c) Some other governments, whose self-identification and founding ideologies are vague, must be included because they have adopted as principal policy measures a set of economic, political, and social policies similar to those followed in openly declared Marxist regimes; for instance, the Seychelles government has announced its intention to eliminate the private ownership of the means of production in order to eliminate exploitation (René 1982, p. 30).

An important implementation condition is that the government must have sufficient political power to effect crucial structural changes in the economy in a socialist direction. In some cases such as the Comoro Islands (the Soilih government), the government did not last long enough to effect these changes. In other countries such as San Marino, the selfproclaimed Communist Party dominated the ruling coalition for some years, but was unable to carry out significant structural reforms. Simi- 
larly, in countries such as Surinam (under Desi Bouterse), Ghana (under Jerry Rawlings), or Chile (under Salvadore Allende), the leading political leaders may have had Marxist sympathies or have been allied politically with Marxists, but they were also unable to institute key structural changes in the economy.

This implementation criterion does not mean that the Marxist party has achieved a "revolutionary breakthrough"- that is, a decisive change in the society-but that it has at least been able to implement a sufficient number of Marxist policies to reveal the orientation of the government. This is because I wish to include in the sample those regimes that have attempted but failed to put major Marxist agricultural organizational ideas into practice in order to be better able to isolate those factors permitting these structural changes to be realized.

My criteria, of course, are difficult to apply because of problems in deciding whether the political beliefs of the dominant party should be considered as Marxist or as some other brand of socialism; for example, African socialism. In addition, the difference between populism and Marxism is often difficult to distinguish (Keller 1987). In two cases (Guyana and Madagascar), the government has proclaimed the strong influence of Marxism on its program, but the Communist Party recognized by the Soviet and other communist parties is not the ruling party. I follow my own criteria and consider these countries as Marxist regimes.

Difficulties of classification also appear concerning countries in which a significant Thermidorean reaction has occurred; that is, where the government or Marxist party has lost its ideological fervor but nevertheless maintains many of the institutions and policies arising when Marxist ideology played a more active role. I have, for instance, included Somalia but excluded Mali since the latter country has maintained fewer of the "socialist institutions." A final problem of classification arises because Marxist-Leninist ideas may no longer be determinant in implementing (in contrast to making) policy. For instance, Mathieu Kérékou, the President of Bénin, had a useful insight when he complained in 1981 that "the government and revolutionary structures no longer exist in reality, for the bureaucrats have virtually seized power on the government's back" (Decalo 1987, p. 11). Although this may have been merely an excuse for his own failures of leadership, there may have been an important element of truth to the statement as well.

Others have treated such borderline cases differently from me because they have examined different issues from those associated with the organization of agriculture, which serves as the focus of this book. Research Note $A$ includes a further discussion of these issues and, in addition, presents three other lists of Marxist nations. My own list has thirty-three countries, of which twenty-six are found in all of the other three lists. At 
least one authority disputes my inclusion of Cape Verde, Guinea-Bissau, Guyana, São Tomé, Seychelles, Somalia, and Zimbabwe, and another disputes my exclusion of Algeria, Burkina Faso, Burma, Burundi, Ghana, Guinea, Mali, Surinam, Syria, Tanzania, and Zambia. These eighteen nations of contention must be considered borderline cases.

To digress for a moment, the difficulties in identifying Marxist regimes impede the development of a theory explaining why certain governments, but not others, have become Marxist regimes. Although this question is best left to political scientists and historians, we can answer a simpler but related question of how the process proceeded. ${ }^{12}$ Nine of the nations became Marxist regimes as a result of decisive military interference by another Marxist nation; eleven, as a consequence of an extensive civil war, either against the existing government or an occupying power; an additional eleven, as the result of a coup or a revolution from above; and two, as the outcome of an election. Of the twenty-four countries that became Marxist without decisive outside interference only one can be considered industrialized (Czechoslovakia) and only one other (Czarist Russia), as semi-industrialized. Fifteen of these nations were also colonies within the last two decades of becoming Marxist regimes, and another five had experienced wars against foreign invaders. Thus the question of why one political-economic system was chosen can be narrowed to the problem of determining the distinguishing characteristics of those poor nations, often recently decolonized or ravaged by war, that are discussed in this study with a similar group of nations that did not become Marxist regimes.

This exercise of determining the path to power provides some interesting clues to how the various governments have functioned. As I show in later chapters, however, it tells us little about how agriculture has been organized or, for that matter, which nations have decollectivized.

Finally, this study focuses primarily on the forty-year period from 1950 to 1990 . Any study dealing with Marxist regimes only in the 1990s would undoubtedly omit a number of countries in my list. For instance, from 1989 through January 1991, the citizens of some of the countries of my sample voted out Marxist governments (Cape Verde, Czechoslovakia, East Germany, Hungary, Nicaragua, and Poland). In others the Marxist regimes disappeared, either as a result of a coup or invasion (Grenada,

\footnotetext{
12 Nations with decisive interference by another Marxist regime include: Bulgaria, East Germany, Hungary, Laos, Kampuchea, Mongolia, North Korea, Poland, and Romania. Nations with extensive civil war include: Albania, Angola, China, Cuba, Guinea-Bissau, Mozambique, Nicaragua, South Yemen, Viet Nam, Yugoslavia, and Zimbabwe. Nations with coups or revolutions from above include: Afghanistan, Bénin, Congo, Czechoslovakia, Ethiopia, Grenada, Guyana, Madagascar, Seychelles, Somalia, and the Soviet Union. Nations with elected Marxist parties include Cape Verde and São Tomé. Among the 24
} 
Somalia) or merger with a non-Marxist regime (South Yemen). In still other nations the top government leaders have either renounced Marxism-Leninism (e.g., Bénin), distanced themselves from these doctrines (e.g., Angola, Mozambique), declared that for their economy MarxismLeninism has failed (e.g., Ethiopia), or reached a state of ideological exhaustion (Guinea-Bissau, Guyana, Madagascar, São Tomé, and parts of Yugoslavia). In a final group of nations the Thermidor will perhaps have proceeded sufficiently far by the mid-1990s so that the label "Marxist regime" would no longer aid analysis. Although prediction is risky, these countries might include Afghanistan, Angola, Bulgaria, Congo, Kampuchea, Laos, and Mongolia. Under certain conditions, as I discuss briefly in chapter 11, it is also possible that some other countries not on my list may become Marxist regimes or that certain countries such as Nicaragua might vote back into power revitalized Marxist parties, especially if the non-Marxist governments prove incapable of dealing successfully with the nation's economic problems. Marxism-Leninism may be ill in the early 1990s, but it is far from dead.

Since this book is a study of the impact of Marxist ideas on the organization of agriculture, it is not vitally important to determine whether $I$ have included all Marxist regimes in the analysis or whether my sample includes some regimes that others consider as non-Marxist. What is critical is that the sample includes a wide enough range of governments in which Marxism has had a crucial influence on agricultural policy so that many national experiences are taken into account.

It is not my intention in this book to march the reader through thirtythree case studies, but rather to use these cases to illuminate a series of general propositions about agricultural organization in Marxist regimes. I present much of the important information about specific countries in tabular form for reference purposes. Thus sufficient data are available for readers who wish to omit some countries from the analysis and to recalculate my statistical results.

\section{Forces Underlying the Role of Agriculture}

In various Marxist regimes agriculture has played different economic roles-as a source of food for the urban areas, as a source of exports, as a source of labor for urban industrial growth, and as a source of finance for urban investment. These roles have differed according to the level of eco-

nations that had become Marxist regimes without decisive outside interference, the following were recent colonies: Angola, Bénin, Cape Verde, Congo, Grenada, Guinea-Bissau, Guyana, Madagascar, Mozambique, São Tomé, Seychelles, Somalia, Viet Nam, South Yemen, and Zimbabwe. The following had also experienced recent wars against foreign aggressors: Albania, China, Czechoslovakia, the USSR, and Yugoslavia. 
nomic development and the available land area, the share of the labor force in agriculture, what foodstuffs are produced, the importance of exports, and other key economic factors. The level of economic development also influences the government's ability to administer a collectivized agricultural sector in a centralized fashion and, as $I$ indicate in chapters 10 and 11 , to carry out a successful decollectivization. The economic size of the nation is important because of the relatively greater economic role of foreign trade in small countries and, I should add with regard to Third World nations, the particularly strategic nature of agricultural exports. Because several of the countries discussed in this study may be unfamiliar to some readers, it is useful to present several tables that summarize these causal factors in a systematic fashion.

\section{Population, Level of Development, and Land Area}

The nations discussed in this study cover a wide range of economic conditions. Table 1.2 shows some key economic variables and table 1.3 summarizes these data from a worldwide perspective. For this exercise it is instructive to divide the Marxist regimes into three groups-core countries of the Socialist Commonwealth, other core countries, and periphery, depending upon their political and economic closeness to the Soviet Union. This type of division provides insight since the three groups have very different economic characteristics and illustrates the heterogeneity of the sample under analysis.

Those core countries classified as belonging to the Socialist Commonwealth have a relatively high per capita income and also a much lower population density (more arable land per capita) than the world average. The other core countries (the numbers are dominated by China) have relatively lower per capita incomes, a much smaller share of the gross world product, and considerably higher population density than the world average. The peripheral nations have a still lower per capita income and a smaller share of the gross world product, but have a population density roughly equal to the world average.

\section{The Importance of Agriculture}

Table 1.4 presents several key indicators of the relative importance of agriculture in the economies of the sample nations. Again, the major message is the heterogeneity of the sample. In later chapters I refer to specific aspects of the data.

The share of the labor force in agriculture gives the simplest picture of its relative weight in the economy: this sector employs three-fifths or more of the labor force in most of the African and Asian Marxist regimes 
in the economy, but in the Marxist regimes in the Americas and Europe this share is much lower. ${ }^{13}$

The value added in agriculture as a percentage of factor price GDP gives another type of measure of the relative importance of agriculture. Dividing this series with data on the share of the labor force in agriculture allows us to compute the relative GDP per economically active in the two sectors which, in turn, provides a comparison of the relative productivities and/or compensation of labor of agricultural and nonagricultural sectors. In the third data column, I designate as "relatively backward" (RB) those agricultural sectors whose relative GDP per worker is less than one-fourth that of the nonagricultural sectors in the same nation. This measure not only indicates those countries where some type of agricultural reorganization is most necessary, but also where such reorganization is most difficult. It is noteworthy that these relatively backward agricultural sectors occur primarily in countries in Africa and Asia. Although Cuba appears an exception, problems with the data in this country may appear because of some anomalies in the pricing of agricultural and nonagricultural products.

The last four columns present some indicators of the role of agriculture in foreign trade. This is important for a later discussion of how, in these countries, an overvalued exchange rate has worked to the particular detriment of agriculture, and an examination of a useful proposition by Colburn (1986) that the private sector in agriculture has a particularly strong bargaining position in those countries where agricultural exports or imports are important. Of the twenty-four countries for which data are available, trade in agricultural goods is relatively unimportant in only five nations (this class is designated as $\mathrm{O}$ in the table), most of which are in East Europe. At the other extreme, agricultural exports play an extremely important role in total exports of nine nations (Bénin, Cuba, Ethiopia, Grenada, Guinea-Bissau, Madagascar, Nicaragua, São Tomé, and Somalia; this class is designated $\mathrm{XX}$ in the table). It is noteworthy that in six of these nine countries, agricultural products play a key role in imports (Cuba, Ethiopia, and Nicaragua are the exceptions), which means not only that their agricultural sectors are relatively specialized

${ }^{13}$ For Cape Verde, Mongolia, Seychelles, and South Yemen natural conditions are not very suitable for agriculture, and this may also be the case for North Korea, which is mountainous. I am puzzled, however, by the inclusion of São Tomé in this list, since it is a very poor nation specializing in agricultural exports. Moreover, this nation has a relatively low degree of urbanization (only 15.6 percent of the population lived in urban areas larger than two thousand people). The census data for 1981 do not suggest that agricultural workers are classified in related industries: the share of the economically active engaged in forestry and fishing is 4.8 percent and in agro-industries, 1.2 percent. The degree to which the São Tomé data are comparable to those of the other nations is unknown. 
TABLE 1.2

Some Key Economic Variables of Marxist Regimes, 1980

\begin{tabular}{|c|c|c|c|c|}
\hline & $\begin{array}{c}\text { Population } \\
\text { (1000s) }\end{array}$ & $\begin{array}{c}\text { Population } \\
\text { per arable } \\
\text { hectares }\end{array}$ & $\begin{array}{c}\text { Per capita GDP } \\
\text { (\% of U.S.) }\end{array}$ & Notes on GDP \\
\hline \multicolumn{5}{|c|}{ Core Countries: Socialist Commonwealth } \\
\hline Bulgaria & 8,862 & 2.1 & $43.0 \%$ & \\
\hline Cuba & 9,724 & 3.0 & 30.9 & Very rough estimate. \\
\hline Czechoslovakia & 15,225 & 2.9 & 61.4 & \\
\hline Germany, East & 16,737 & 3.3 & 69.2 & \\
\hline Hungary & 10,771 & 2.0 & 48.3 & \\
\hline Kampuchea & 6,400 & 2.1 & 4.2 & Very rough estimate. \\
\hline Laos & 3,683 & 4.2 & 4.2 & Very rough estimate. \\
\hline Mongolia & 1,663 & 1.4 & 4.2 & Very rough estimate. \\
\hline Poland & 35,578 & 2.4 & 43.9 & \\
\hline Romania & 22,201 & 2.1 & 34.6 & \\
\hline Viet Nam & 54,175 & 8.2 & 2.8 & Very rough estimate. \\
\hline USSR & 265,542 & 1.1 & 49.3 & \\
\hline Total & 450,501 & & & \\
\hline Weighted average & & 1.5 & 42.2 & \\
\hline \multicolumn{5}{|l|}{ Core Countries: Other } \\
\hline Albania & 2,671 & 3.8 & 20.7 & Very rough estimate. \\
\hline China & $1,017,561$ & 10.2 & 10.3 & See note below. \\
\hline Korea, North & 18,025 & 8.0 & 10.4 & Very rough estimate. \\
\hline Yugoslavia & 22,295 & 2.8 & 41.5 & \\
\hline Total & $1,060,552$ & 9.6 & & \\
\hline Weighted average & & 1.1 & 11.0 & \\
\hline \multicolumn{5}{|c|}{ Countries of the Periphery } \\
\hline Afghanistan & 15,950 & 2.0 & 5.2 & \\
\hline Angola & 7,581 & 2.2 & 6.1 & \\
\hline Bénin & 3,464 & 1.9 & 4.7 & \\
\hline Cape Verde & 296 & 7.4 & 8.3 & \\
\hline Congo & 1,605 & 2.4 & 8.6 & \\
\hline Ethiopia & 37,717 & 2.7 & 2.8 & \\
\hline Grenada & 89 & 6.4 & 13.2 & \\
\hline Guinea-Bissau & 809 & 2.8 & 3.4 & \\
\hline Guyana & 792 & 1.6 & 14.2 & \\
\hline Madagascar & 8,714 & 2.9 & 5.2 & \\
\hline Mozambique & 12,094 & 3.9 & 5.6 & \\
\hline Nicaragua & 2,672 & 2.1 & 17.6 & \\
\hline São Tomé & 94 & 2.6 & 6.0 & \\
\hline Seychelles & 63 & 12.6 & 18.4 & \\
\hline Somalia & 4,674 & 4.4 & 3.6 & \\
\hline Yemen, South & 1,969 & 12.6 & 4.7 & \\
\hline
\end{tabular}


TABLE 1.2 (cont.)

\begin{tabular}{|c|c|c|c|c|}
\hline & $\begin{array}{l}\text { Population } \\
\text { (1000s) }\end{array}$ & $\begin{array}{c}\text { Population } \\
\text { per arable } \\
\text { hectares }\end{array}$ & $\begin{array}{l}\text { Per capita GDP } \\
\text { (\% of U.S.) }\end{array}$ & Notes on GI \\
\hline Zimbabwe & 6,976 & 2.7 & 8.2 & \\
\hline Total & 105,559 & & & \\
\hline Weighted average & & 2.7 & 5.0 & \\
\hline $\begin{array}{l}\text { Grand total } \\
\text { Grand weighted } \\
\text { average }\end{array}$ & $1,616,612$ & 3.7 & 19.3 & \\
\hline \multicolumn{5}{|c|}{$\begin{array}{l}\text { Source: The population data come from United Nations (1988a, table 3), the land data come from } \\
\text { and Agricultural Organization (data files), and most GDP data come from Robert Summers and } \\
\text { Heston (1988). } \\
\text { Notes: Summers and Heston (1988) estimate the per capita GDP of China as } 264 \text { percent that of } \\
\text { the World Bank (annual, } 1982, \mathrm{p} .110) \text { estimates the same statistic as } 121 \text { percent that of India. I } \\
\text { taken an unweighted average as my estimate. The estimates designated as "very rough" represent } \\
\text { more than educated guesses on my part. }\end{array}$} \\
\hline \multicolumn{5}{|c|}{$\begin{array}{c}\text { TABLE } 1.3 \\
\text { Summary of Key Economic Parameters of Marxist Regimes }\end{array}$} \\
\hline \multirow{2}{*}{\multicolumn{2}{|c|}{ Groups of Nations }} & \multicolumn{3}{|c|}{ Percent of World } \\
\hline & & Population & Arable Land & $G D P$ \\
\hline \multicolumn{5}{|c|}{ Classified by Political Criteria } \\
\hline \multicolumn{5}{|l|}{ Core Countries } \\
\hline Socialist Con & onwealth & $10.0 \%$ & $20.1 \%$ & $15.8 \%$ \\
\hline Other & & 23.6 & 7.6 & 9.7 \\
\hline Countries of $P$ & hery & 2.4 & 2.7 & 0.4 \\
\hline Total & & 36.0 & 30.4 & 26.0 \\
\hline \multicolumn{5}{|c|}{ Classified by Continents } \\
\hline Africa & & 1.9 & 2.1 & 0.3 \\
\hline America & & 0.3 & 0.3 & 0.3 \\
\hline Asia & & 25.0 & 8.3 & 9.2 \\
\hline Europe & & 8.9 & 19.6 & 16.2 \\
\hline Total & & 36.0 & 30.4 & 26.0 \\
\hline
\end{tabular}

Source: See Table 1.2.

Notes: To calculate these percentages for the GDP, I had to make rough estimates for nations not included in the calculations by Summers and Heston (1988). 


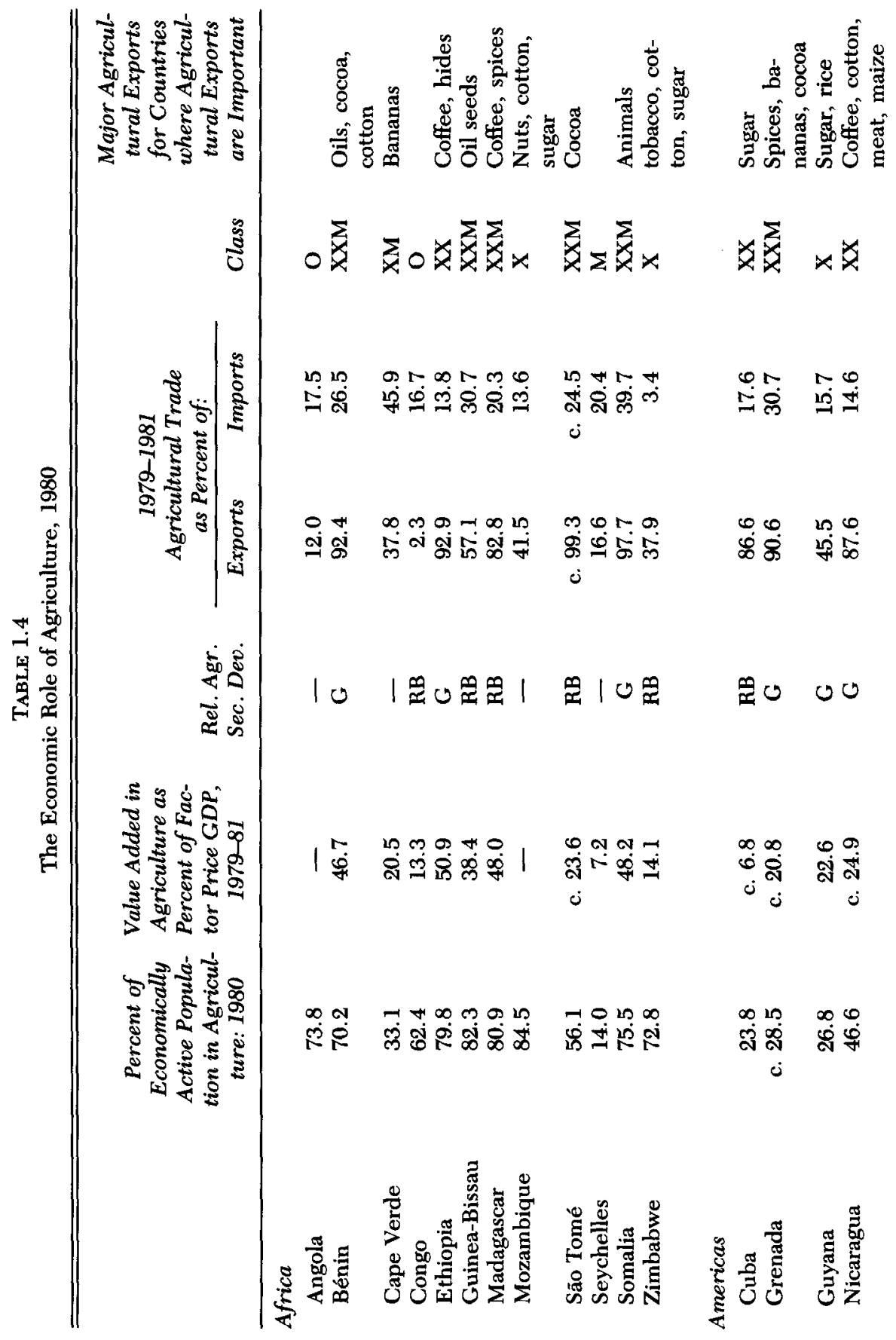




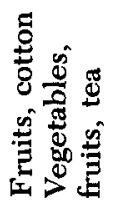

㜔 111110 |101x 0120

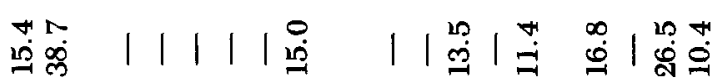

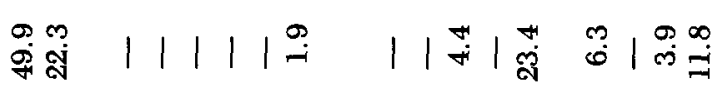

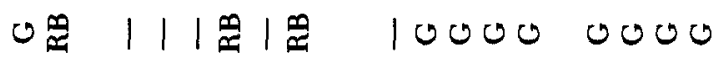

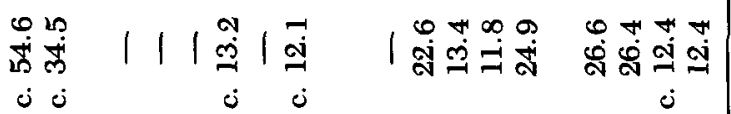

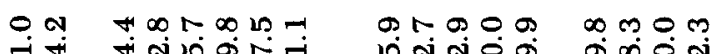

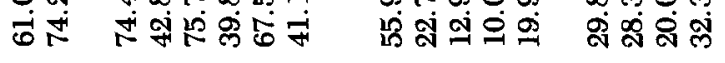

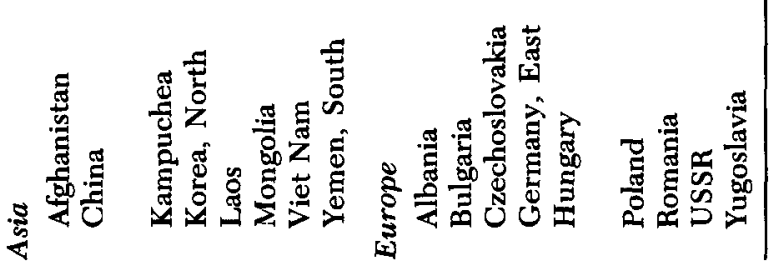

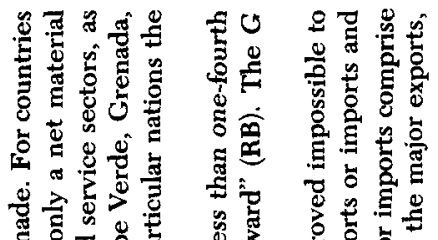

日

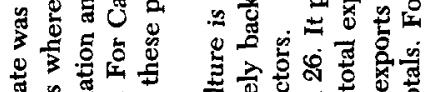

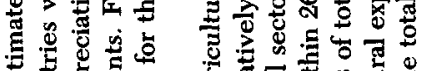

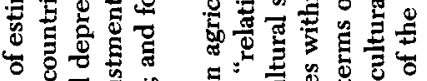

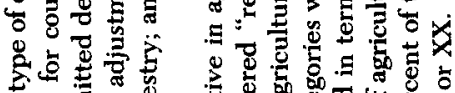

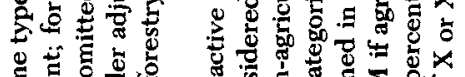

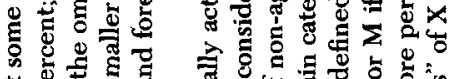

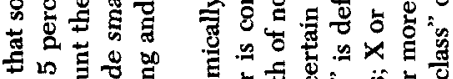

公要结

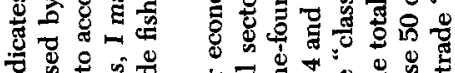

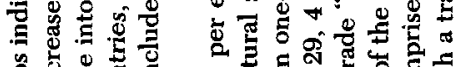

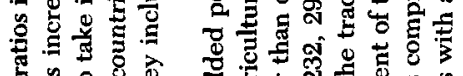

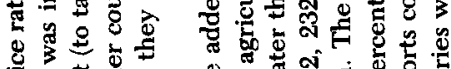

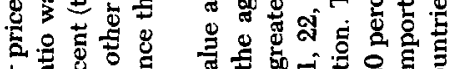

โ

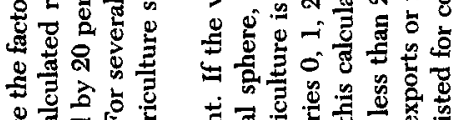

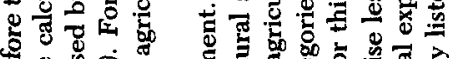

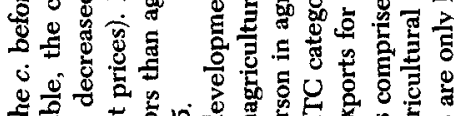

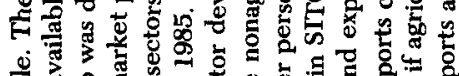

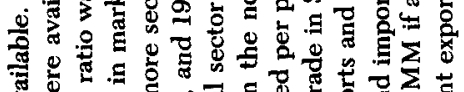

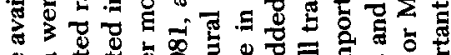
논 ฐू $<00 \%$

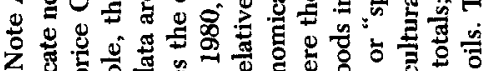

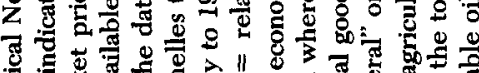

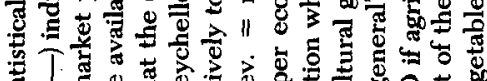

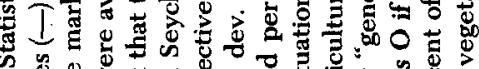
का के

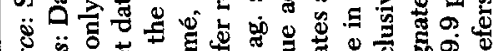

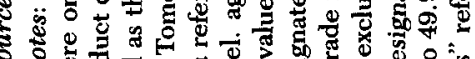

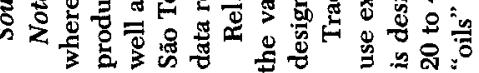


but also that they face more risks on the world market because of their lack of self-sufficiency in food. Later chapters discuss the role of these factors in a more rigorous and thorough fashion.

\section{Plan of Attack}

For the most part I have based this study on the primary and secondary literature of the thirty-three nations under review, supplemented by unpublished reports of international organizations. For some chapters, particularly those dealing with the most recent agricultural reforms, I have also used materials gathered from interviews of experts and government officials both inside and outside of the nations, as well as from discussions with farm directors and workers in eight of the nations under review.

Any broad study of the economic organization of agriculture in Marxist regimes must deal with five major topics: the important ideological views about the sector; the origin and development of the major forms of productive units; the internal organization of the farms and their external links with related sectors; major governmental agricultural policies and their results; and the changes in the organizational structure in recent years. These topics guide the analysis in the following chapters.

The next chapter, which forms the second segment of this introduction, focuses on both the general Marxist doctrines on agriculture and the policy issues leading to collectivization. Although classical Marxist writers wrote extensively about agriculture, they included little discussion about collectivization or the organization of agriculture in the transition to communism. This raises a number of questions: To what extent are the parallels drawn by Marx between the paths of economic development in agriculture and industry persuasive? To what degree have Marxian predictions about developments in agriculture been validated in leading capitalist nations over the last century? If, as I argue, only partial responsibility for agricultural collectivization can be laid at the doorstep of Marx, what were the other crucial elements in this decision in the Soviet Union? If many of the specific policy problems leading to Soviet collectivization were specific to that country, why did most other Marxist regimes also collectivize? To answer these and similar questions, it is essential to separate Marxist propositions, attitudes, and examples and to provide some notion of the range of policies receiving justification from the same doctrinal source.

\section{Land Reforms and Collectivization}

This part deals with the painful processes of creating a socialist agricultural sector. Most, but not all Marxist regimes have carried out land re- 
forms, but the specific measures of these reforms have been quite different. The most important causal mechanisms for these differences receive considerable attention and give rise to a number of questions: How can the different types of land reform measures be explained? Why have certain Marxist nations collectivized and others not? What are the key relationships between the land reform and collectivization processes? Why have different countries focused either on state farms or collective farms? And why have various Marxist regimes taken very different strategies to achieve full collectivization? The comparative analyses in chapters 3 and 4 provide useful clues for the answers to these questions.

\section{Structural Elements}

Chapters 5 and 6 focus attention on both external and internal organizational issues. The former refers to horizontal and vertical integration of the farms; that is, the size of the farms and the manner in which they obtain inputs and sell their outputs. The latter refers to the way in which the state and collective farms organize their productive activities and compensate their labor force. From the descriptive materials a number of questions arise: Why have collective and state farms continued to grow in size over the years? How do the various ways for resolving problems of external organization influence the performance of the agricultural sector or the ease with which decollectivization can occur? What are the competitive and complementary elements between the socialist agricultural sector and the individual plots that are allowed farmers on collective farms? What are the options facing collective and state farm managers in organizing production and how does this choice effect performance or the speed of organizational change? The analysis yields insights into these questions and is supplemented by a research note presenting a model of decision-making by collective and state farm directors in a centrally planned economy in order to show in a rigorous fashion why it is likely that the dynamic efficiency of these farms is lower than in market economies.

\section{Policy and Performance}

The performance of agriculture is influenced not just by the organizational structure, but also by governmental policies. Chapter 7 deals with policies issues and three critical questions about them: Although policies vary a great deal from one country to another, depending upon the specific agricultural conditions, what are the elements common to all? To what extent are these policies distinctly influenced by Marxist doctrines? And to what extent are such policies tied to the organizational structure 
of agriculture? In chapter $8 \mathrm{I}$ examine what the major differences are in agricultural performance between Marxist and non-Marxist nations. This quantitative exercise requires a separation of the respective influences of Marxist ideology in general, central economic planning of agriculture, and collectivization. I place particular emphasis on dynamic, rather than static, criteria of evaluation and show that the lower growth of total factor productivity is the major distinguishing characteristic of Marxist agriculture. This conclusion parallels Murrell's (1989) empirical analysis of Marxist foreign trade showing that these nations have a lower generation and adoption of technological and organizational innovation than comparable nations in the West.

\section{Reforms and the Future}

In chapter 9 I examine the question of decollectivization from the viewpoint of the farmer and try to review those factors that increase the difficulty of the process. For instance, decollectivization is more likely to occur in Marxist regimes with agricultural sectors employing a relatively simple technology than in those nations which have a relatively mechanized agriculture and in those countries where property rights can be enforced. In the next two chapters I analyze problems of the reform of the organization of agriculture from the viewpoint of the government. In chapter $10 \mathrm{I}$ investigate the different types of agricultural reforms taking place in the various Marxist regimes at the beginning of the 1990s and explore the major problems arising in changing the property relations, of marketizing the agricultural sector, and of changing farm management practices. A research note covers in greater detail the agricultural reforms in China, Guyana, Hungary, and the USSR. Chapter 11 provides an analysis of some macroeconomic issues, including the phasing of economic and political reforms and the timing of particular economic changes that play a major role in the success of agricultural reforms. The book ends with some reflections on the rise and possible fall of collectivized agriculture.

The furrow plowed in this book is long and difficult, and at this point the fruitfulness of the harvest is far from certain. Much more can be said about what should be done and how it should be accomplished, but since the major goals of the analysis should be clear, this prologue should end. Now it is time to roll up our sleeves and begin. 